\title{
Aspek Hukum Pidana Dalam Kecelakaan Kerja \\ Serta Tanggung Jawab Korporasi Bagi Keluarga Korban Berbasis Keadilan (Study Kasus Di PT Semen Gresik Kabupaten Rembang)
}

\author{
Samodra Kharisma Aji Sugiyanto ${ }^{*}$, Djauhari ${ }^{* *}$, Akhmad Khisni $^{* * *}$
}

\begin{tabular}{l} 
* Mahasiswa Program Magister (S2) Ilmu Hukum Fakultas Hukum UNISSULA Semarang, email \\
odasamodra@gmail.com \\
${ }^{* *}$ Dosen Fakultas Hukum UNISSULA Semarang \\
${ }^{* * *}$ Dosen Fakultas Hukum UNISSULA Semarang \\
\hline
\end{tabular}

\begin{abstract}
ABSTRAK
Dalam penelitian ini permasalahan yang akan dibahas yaitu Sistem Manajemen Keselamatan dan Kesehatan Kerja Bila Dipandang Dari Aspek Hukum Pidana, Kelemahan Sistem Manajemen Keselamatan dan Kesehatan Kerja Dari Sudut Pandang Pengaturan Perundang-Undangan dan Tanggung Jawab Korporasi Yang Ideal Bagi Korban Kecelakaan Kerja Yang Berbasis Keadilan Di PT Semen Gresik Kabupaten Rembang.

Penelitian ini menggunakan metode pendekatan secara yuridis sosiologis. Adapaun sumber dan jenis data dalam penelitian ini adalah data primer yang diperoleh dari studi lapangan dengan wawancara. Dan data sekunder diperoleh dari studi kepustakaan.

Kesimpulan dari penilitian ini adalah upaya perlindungan preventif dengan menyediakan klinik yang dapat digunakan untuk berobat apabila terjadi kecelakaan kerja dan upaya perlindungan represif yaitu memberikan santunan yang besaran nominalnya 1,5 \% dari yang seharusnya yaitu sebesar Rp. 300.000 (maksimum) untuk berobat diluar klinik yang disediakan pihak hotel serta tidak memotong jam kerja pekerja yang ijin berobat pada saat jam kerja. Pengawasan pemerintah yang sangat kurang dalam pelaksanaan undang-undang Perusahaan yang masih minim modal dalam peningkatan pelayanan K3 untuk karyawannya. Kurangnya publikasi dan pengetahuan tentang Keselamatan dan Kesehatan Kerja, terutama untuk masyarakat pedesaan. Perusahaan pengangkutan wajib mengasuransikan pekerja yang diperkerjakan sebagai awak kendaraan karena awak kendaraan merupakan pekerjaan yang memilik risiko tertinggi dalam usaha pengangkutan apabila terjadi kecelakaan di jalan.
\end{abstract}

Kata kunci: Aspek Hukum Pidana, Kecelakaan Kerja, Korporasi

\begin{abstract}
This research, the issues that will be discussed are Safety Management System and Occupational Health when Viewed From Criminal Law Aspect, Weakness of Occupational Safety and Health Management System From The Point of View of Legal Arrangement and Corporate Responsibility Ideal for Victims of Justice-Based Accidents at PT Semen Gresik Kabupaten Rembang.

This research uses sociological juridical approach method. Adapaun source and data type in this research is primary data obtained from field study by interview. And secondary data obtained from literature study.

The conclusion of this research is preventive protection effort by providing clinic that can be used for medical treatment when the work accident and repressive protection effort is giving the compensation of the nominal amount 1.5\% from the supposed that is equal to Rp. 300.000 (maximum) for treatment
\end{abstract}


outside the clinic provided by the hotel and does not cut work hours of workers who permit treatment during working hours. Government supervision is very lacking in the implementation of Company law that still lack of capital in the improvement of OSH services for its employees. Lack of publications and knowledge of Occupational Safety and Health, especially for rural communities. The haulage company is required to insure the worker employed as a crew of a vehicle because the crew is the occupier who has the highest risk in the transportation business in the event of an accident on the road.

Keywords: Criminal Law Aspect, Work Accident, Corporation

\section{PENDAHULUAN}

Pembangunan ketenagakerjaan mempunyai banyak dimensi dan keterkaitan. Keterkaitan itu tidak hanya dengan kepentingan tenaga kerja selama, sebelum dan sesudah masa kerja tetap juga keterkaitan dengan kepentingan pengusaha, pemerintah, dan masyarakat. Untuk itu, diperlukan pengaturan yang menyeluruh dan komperehensif, antara lain mencakup pengembangan sumber daya manusia, peningkatan produktivitas dan daya saing tenaga kerja, dan pembinaan hubungan industrial. ${ }^{1}$

Sejalan dengan itu maka didalam Undang-Undang Republik Indonesia Nomor 1 Tahun 1970 tentang keselamatan kerja menimbang bahwa :2

1. Setiap tenaga kerja berhak mendapat perlindungan atas keselamatannya dalam melakukan pekerjaan untuk kesejahteraan hidup dan meningkatkan produksi serta produktivitas Nasional;

2. Setiap orang lainnya yang berada di tempat kerja perlu terjamin pula keselamatannya;

3. Setiap sumber produksi perlu dipakai dan dipergunakan secara aman dan effisien;

4. Berhubung dengan itu perlu diadakan segala daya upaya untuk membina norma-norma perlindungan kerja;

5. Bahwa pembinaan norma-norma itu perlu diwujudkan dalam Undang-undang yang memuat ketentuan-ketentuan umum tentang keselamatan kerja yang sesuai dengan perkembangan masyarakat, industrialisasi, teknik dan teknologi.

Peran tenaga kerja sebagai modal usaha dalam melaksanakan pembangunan harus didukung juga dengan jaminan hak setiap pekerja, ${ }^{3}$ pemenuhan perlindungan terhadap tenaga kerja menjadi tanggung jawab pemerintah yang kemudian dituangkan dalam peraturan kemudian harus dijalankan oleh setiap perusahaan, pemerintah serta perusahaan harus saling bersinergi agar terwujudnya jaminan keselamatan dan kesehatan bagi pekerja.

Menurut Pasal 99 Undang-Undang Nomor 13 Tahun 2003 tentang Ketenagakerjaan setiap pekerja/buruh dan keluarganya berhak untuk memperoleh jaminan sosial tenaga kerja. Dalam ketentuan tersebut Jamsostek merupakan suatu hak yang tidak hanya dimiliki oleh pekerja/buruh tetapi juga keluarga. Pemberian hak kepada pekerja/buruh ini dimaksudkan untuk memberikan jaminan pelayanan bila ada anggota keluarga pekerja/buruh mengalami sakit atau memerlukan bantuan medis lain seperti hamil dan melahirkan serta mereka yang mendapatkan kecelakaan kerja. ${ }^{4}$

Ketentual pasal tersebut bertujuan untuk menjamin keselamatan para pekerja dalam menjalankan pekerjaannya. Menurut Menteri Tenaga Kerja dan Transmigrasi A. Muhaimin Iskandar yang dikutip dari poskotanews.com bahwa:

Saat ini, dari 4.057 perusahaan yang diperiksa, tercatat ada 3.517 perusahaan yang mendapat

\footnotetext{
${ }^{1}$ Lihat Penjelasan atas Undang-Undang Nomor 13 Tahun 2003 tentang Ketenagakerjaan

2 Bandingkan dengan Undang-Undang Nomor 1 Tahun 1970 tentang Keselamatan Kerja

${ }^{3}$ Asri Wijayanti, 2009, Hukum Ketenagakerjaan Pasca Reformasi, Sinar Grafika, Jakarta, h. 6

${ }^{4}$ Maimun, 2004, Hukum Ketenaga Kerjaan Suatu Pengantar, , Pradnya Paramita, Jakarta h.86
} 
surat peringatan dari pengawas agar menjalankan kegiatan perusahaan sesuai dengan peraturan $\mathrm{K} 3,^{\prime \prime}$

Berdasarkan data PT Jamsostek, selama semester I/2011, terdapat sekitar 48.515 kecelakaan kerja, sedangkan International Labour Organization (ILO) mencatat setiap hari terjadi kecelakaan kerja yang mengakibatkan korban fatal dengan 6.000 kasus. $^{6}$

Sementara itu kecelakaan kerja pernah terjadi di Pabrik Semen Rembang seorang pekerja meregang nyawa setelah tertimpa Mobil Crane kejadian tersebut adalah kejadian yang kedua, sebelumnya telah terjadi kecelakaan serupa yang mengakibatkan seseorang meninggal dunia dan 2 pekerja mengalami luka berat. Sementara satu diantaranya mengalami luka ringan kecelakaan tersebut terjadi diarea PT. Semen Indonesia Plant Site Area dimana para korban tertimpa beton cor. Berdasarkan permasalahan tersebut di atas dan juga masih minimnya penelitian terhadap tanggung jawab korporasi bagi korban dalam kecelakaan kerja, maka penulis sangat tertarik untuk mengadakan penelitian dengan judul "Aspek Hukum Pidana Dalam Kecelakaan KerjaSerta Tanggung Jawab Korporasi Bagi Keluarga Korban Berbasis Keadilan (Study Kasus Di PT Semen Gresik Rembang)", dengan harapan dapat menemukan jawaban atas rumusan masalah yang akan dikaji nantinya. Dari uraian diatas serta melihat kasus yang terjadi di PT Semen Indonesia maka Penulis mencoba mengkat Rumusan Masalah sebagai berikut :

1. Bagaimana Sistem Managemen Keselamatan dan Kesehatan Kerja Bila Dipandang Dari Aspek Hukum Pidana?

2. Apa Kelemahan Sistem Manajemen Keselamatan dan Kesehatan Kerja Dari Sudut Pandang Pengaturan Perundang-Undangan Dari Aspek Hukum Pidana?

3. Bagaimana Tanggung Jawab Korporasi Yang Ideal Bagi Korban Kecelakaan Kerja Yang Berbasis Keadilan?

\section{PEMBAHASAN}

\section{Sistem Manajemen Keselamatan Dan Kesehatan Kerja Bila Di Pandang Dari Aspek Hukum Pidana}

Pemerintah dalam rangka mewujudkan keselamatan dan kesehatan kerja menerbitkan peraturan perundang-undangan, diantaranya: Undang-Undang No. 1 Tahun 1970 tentang Keselamatan Kerja, Undang-Undang No. 13 Tahun 2013 tentang Ketenagakerjaan, dan Peraturan Pemerintah No. 50 Tahun 2012 tentang Penerapan Sistem Manajemen Keselamatan dan Kesehatan (SMK3), serta peraturan lainnya. Peraturan terkait keselamatan dan kesehatan kerja dimaksud tidak lain berupa patokan atau pedoman untuk berprilaku secara pantas, yang sebenarnya merupakan suatu pandangan dan sekaligus harapan. Patokan-patokan tersebut sering dikenal dengan sebutan norma atau kaedah yang mengatur diri pribadi manusia dalam pergaulan hidup di masyarakat. ${ }^{7}$

Perkembangan hukum ketenagakerjaan yang berlaku di Indonesia sejak zaman sebelum kemerdekaan sampai saat ini, telah terjadi pergeseran istilah yang disebabkan oleh berbagai alasan baik yang bersifat sosiologis maupun yuridis. Sampai saat ini belum ada kesatuan pendapat mengenai pengertian mengenai hukum ketenagakerjaan. Akan tetapi secara umum dapat dirumuskan, bahwa hukum ketenagakerjaan itu adalah sekumpulan peraturan yang mengatur hubungan hukum antara pekerja atau organisasi pekerja dengan majikan atau pengusaha atau organisasi majikan dan

\footnotetext{
${ }^{5}$ http://poskotanews.com/2012/01/12/pelanggar-k3-bisa-dipidana/ diakses pada tanggal 7 Desember 2017 pada Pukul 17.10

${ }^{6}$ Ibid

${ }^{7}$ Soerjono Soekanto, 2013, Faktor-Faktor Yang Mempengaruhi Penegakan Hukum, Cet. ke-12, Jakarta, Rajawali Press, Hal 23.
} 
pemerintah, termasuk didalamnya adalah proses-proses dan keputusan-keputusan yang dikeluarkan untuk merealisasikan hubungan tersebut menjadi kenyataan. Dari rumusan tersebut dapat ditarik suatu kesimpulan, bahwa hukum ketenagakerjaan itu adalah suatu himpuna peratuaran yang mengatur hubungan hukum antara pekerja, majikan atau pengusaha, organisasi pekerja, organisasi pengusaha, dan pemerintah. ${ }^{8}$

Upaya kesehatan kerja bertujuan untuk melindungi pekerja atau buruh guna mewujudkan produktivitas kerja yang optimal, dengan cara pencegahan kecelakaan dan penyakit akibat kerja, pengendalian bahaya ditempat kerja, promosi kesehatan, pengobatan, dan rehabilitasi. Dengan demikian tujuan kesehatan kerja adalah :

a. Melindungi pekerja dari resiko kesehatan kerja.

b. Meningkatkan derajat kesehatan para pekerja atau buruh.

c. Agar pekerja atau buruh dan orang-orang disekitarnya terjamin kesehatannya.

d. Menjamin agar produksi dipelihara dan dipergunakan secara aman dan berdaya guna. Setiap pengusaha wajib melaksanakan ketentuan waktu kerja sebagaimana dimaksud dalam Pasal 77 Ayat (1) Undang-Undang Nomor 13 Tahun 2003 yang meliputi :

1. 7 (tujuh) jam 1 (satu) hari dan 40 (empat puluh) jam 1 (satu) minggu untuk 6 (enam) hari kerja dalam 1 (satu) minggu; atau

2. 8 (delapan) jam 1 (satu) hari dan 40 (empat puluh) jam 1 (satu) minggu untuk 5 (lima) hari kerja dalam 1 (satu) minggu.

Menurut Zainal Asikin, Problematika yang terjadi secara umum di nasional ini pokok pangkal kekurang puasan pada umumnya berkisar pada masalah: ${ }^{9}$

1. Pengupahan.

2. Jaminan sosial.

3. Perilaku penugasan yang kadang-kadang dirasakan kurang sesuai dengan kepribadian.

4. Daya kerja dan kemampuan kerja yang dirasakan kurang dengan pekerjaan yang harus diemban.

5. Adanya masalah pribadi.

Ditambah lagi dilingkup tenaga kerja tidak tetap, sering tidak mendapatkan perlindungan hukum dan tidak mendapatkan perlakuan yang sama dengan tenaga kerja tetap. Suatu peraturan perusahaan tidak boleh bertentangan dengan peraturan perundangan yang berlaku, dan mulai berlaku setelah disahkan oleh pejabat yang ditunjuk. Pengusaha wajib memberitahukan dan menjelaskan tentang peraturan perusahaan kepada tenaga kerja. Perlindungan pekerja dari kekuasaan pengusaha terlaksana apabila peraturan dalam bidang ketenagakerjaan yang mengharuskan atau memaksa pengusaha bertindak seperti dalam peraturan perundang-undangan tersebut benar-benar dilaksanakan semua pihak karena keberlakuan hukum tidak dapat diukur secara yuridis saja, tetapi diukur secara sosiologi dan filosofis. ${ }^{10}$

Tujuan dari penerapan Sistem Manajemen Keselamatan dan Kesehatan Kerja ini antara lain:

1. Menempatkan tenaga kerja sesuai dengan harkat dan martabatnya sebagai manusia.

2. Meningkatkan komitmen pimpinan dalam melindungi tenaga kerja.

3. Meningkatkan efisiensi dan produktivitas kerja untuk menghadapi globalisasi.

4. Proteksi terhadap industri dalam negeri.

\footnotetext{
${ }^{8}$ Darwin Prinst, Hukum Ketenagakerjaan Indonesia (Buku Pegangan Pekerja Untuk Mempertahankan hak-haknya), Penerbit Citra Aditya Bakti, Bandung, 1994, hal. 1

${ }^{9}$ R. Joni Bambang S., S.H., MM, 2013, Hukum Ketenagakerjaan, Bandung: Pustaka Setia, hal 289

${ }^{10}$ Dian Octaviani Saraswati, "Perlindungan Hukum Keselamatan dan Kesehatan Terhadap tenaga Kerja di Perusahaan tenun PT. Musitex Kabupaten Pekalongan” Tesis Mahasiswa Universitas Diponegoro (2017), hal 37.
} 
5. Meningkatkan daya saing dalam perdagangan internasional.

6. Mengeliminir boikot LSM internasional terhadap produk ekspor nasional.

7. Meningkatkan pencegahan kecelakaan melalui pendekatan sistem.

8. Pencegahan terhadap problem sosial dan ekonomi terkait dengan penerapan $\mathrm{K} 3 \mathrm{~L}$.

Terdapat 6 dasar hukum yang sering menjadi acuan mengenai K3 yaitu :

a. Undang-Undang No. 1 Tahun 1970 Tentang Keselamatan Kerja.

b. Undang-Undang No. 21 Tahun 2003 tentang Pengesahan ILO Convention.

c. Undang-Undang No. 13 Tahun 2003 tentang Ketenagakerjaan, Khususnya

d. Keputusan Menteri Tenaga Kerja RI No: PER.155/MEN/1984

e. Peraturan Menteri Tenaga Kerja RI No: PER.04/MEN/1987

f. Peraturan Menteri Tenaga Kerja RI No. 05/MEN/1996

Penerapan sanksi pidana terhadap yang melakukan pelanggaran di bidang ketenagakerjaan terdapat dalam pasal 183 sampai dengan pasal 189 Undang-Undang Nomor 13 tahun 2003 sanksi pidana tersebut berupa sanksi pidana penjara, kurungan dan denda. Sedangkan penerapan sanksi administrasinya terdapat dalam pasal 190 Undang-Undang No. 13 tahun 2003 yaitu berupa :
a. Teguran
b. Peringatan tertulis
c. Pembatasan kegiatan usaha
d. Pembekuan kegiatan usaha
e. Pembatasan persetujuan
f. Pembatasan pendaftran
g. Penghentian sementara sebagai atau seluruh alat produksi
h. Pencabutan izin

Dengan demikian dapat disimpulkan bahwa sistem manajemen keslematan dan kesehatan kerja bagi tenaga kerja perlu diprioritaskan agar tidak banyak makan korban dari kecelakaan kerja. Berdasarkan hasil penerapan tentang aspek hukum terhadap keselamatan sanksi kepada pekerja tersebut sesuai dengan aturan yang ditetapkan oleh perusahaan. Menerapkan K3 sesuai dengan peraturan perundang-undangan secara tidak langsung perusahaan dapat mencegah terjadinya kecelakaan dan penyakit kerja serta pelanggaran kerja. Dan juga pekerjaan dapat terlaksana dengan aman dan efisien seperti yang dijelaskan dalam undang-undang yang berbunyi dalam pasal 183 sampai 189 Nomor 13 tahun 2003 sanksi pidana tersebut berupa sanksi pidana penjara, kurungan dan denda, tentang bagi yang melanggar aturan ketenagakerjaan. Jadi perlu di embangkan bagi tenga kejra agar mematuhu aturan yang ditetapkan oleh pemerintah ataupun perusahan tersebut agar tidak terjadi kecelakaan kerja. Sistem manajemen kerja yang telah di evaluasi oleh pemerintah maupun pihak dari perusahaan bahwa kualitas sumber daya manusia perlu ditingkatkan agar terwujud tenaga kerja yang berkualitas, berkomptensi, dan efektivitas serta efisien agar tercapai tujuan perusahan tersebut.

Dalam mengembangkan sistem manajemen keselamatan kerja dan kesehatan kerja perlu adanya suatu pelatihan-pelatihan bagi tenaga kerja agar tidak sering terjadi kecelakaan dalam melaksanakan pekerjaan di dalam perusahaan. Olehnya itu perlu adanya kesadaran bagi tenaga kerja agar lebih berhati-hati dalam melakukan aktifitas kegiatan sehari-hari dalam artian tenaga kerja. Perlindungan hukum bagi tenaga kerrja sangat dibutuhkan oleh setiap pekerja, karena dalam tinjauan yuridis hukum ketenagakerjaan berbeda dengan kondisi yang ada dalam praktik lapangan. Maka dari itu, dalam mengangkat tema tersebut agar penegakan hukum di Indonesia dapat berjalan. Terjadinya hubungan yang jelas antara pengusaha dengan pekerja dan tidak ada pihak yang dirugikan dalam hubungan kerja. Para pekerja dan pengusaha sama-sama dapat mensejahterakan kehidupannya. 


\section{Kelemahan Sistem Manajemen Keselamatan Dan Kesehatan Kerja Dari Sudut Pandang Pengaturan Perundang-Undangan}

Dalam Undang-undang tentang keselamatan kerja No. 1 tahun 1970 pasal 2, memberikan perlindungan keselamatan dan kesehatan kerja meliputi dari semua aspek pekerjaan yang berbahaya, dari semua tempat kerja, baik darat, di dalam tanah, permukaan air, dalam air maupun di udara yang berada di wilayah kekuasaan hukum Republik Indonesia. Berikut ini ada beberapa sebab yang memungkinkan terjadinya kecelakaan dan gangguan kesehatan antara lain: ${ }^{11}$

1. Keadaan tempat lingkungan kerja

2. Pengaturan udara

3. Pengaturan penerangan

4. Pemakaian peralatan kerja

5. Kondisi fisik dan mental

Solusi untuk permasalahan ini adalah dengan memberi sanksi yang tegas terhadap paerusahaan tersebut dan dalam pelakassanaan peraturan tersebut, perlu adanya pengawasan yang ketat agar tidak ada lagi pelanggaran, serta kesehatan karyawan dapat terjaga dengan baik.

Berikut beberapa hasil kutipan dari buku tentang Kesehatan dan Keselamatan Kerja halaman 14:

1. Pasal 23 ayat 2:

Kesehatan kerja memliputi pelayanann kesehatan kerja, pencegahan penyakit akibat kerja dan syarat kesehatan kerja.

2. Pasal 23 ayat 3 :

Setiap pekerja wajib menyelenggarakan kesehatan kerja

3. Pasal 84 ayat 3:

Barang siapa siapa menyelenggarakan tempat kerja yang tidak memenuhi ketentuan sebagaimana dimaksud dalam pasal 23 ayat 3 bahwa pelaku akan dipidan kurungan selama 1 tahun atau pidana denda paling banyak Rp.15.000.000 (Lima belas juta rupiah). Dari beberapa pasal diatas jelas tertulis bahwa setiap perusahan yang tidak memenuhi pelayanan kesehatan untuk para pekerjanya dapat di kenai sanksi berupa kurungan selama 1 tahun dan denda paling banyak 15 juta.

Untuk mengatasi permasalahan ini perlu ada tindakan khusus dari pemerintah atau lembaga K3 yang ada di Indonesia untuk mengatasi masalah ini misalnya dengan memberikan penyuluhan terhadap warga desa tentang betapa pentingnya tentang keselamatan dan kesehatan kerja di lingkungan kerja agar mereka menyadari betapa pentingnya penerapan K3 di lingkungan kerja. Dengan salah satu cara ini pemerintah sudah melaksanakan kebijakan perundang-undangan Permenakertrans RI No 1 Tahun 1978 tentang Keselamatan dan Kesehatan Kerja dalam Pengangkutan dan Penebangan Kayu secara nyata. ${ }^{12}$

Diharapkan dengan cara penyuluhan atau sosialisasi tersebut dapat mengurangi kecelakaan kerja yang terjadi karena pekerjaan ini merupakan pekerjaan yang resikonya cukup tinggi (High Risk). Maka dari itu pekerjaan ini harus dilengkapi dengan alat perlindugan diri yang lengkap dan juga perlu adanya asuransi,misal BPJS ketenagakerjaan agar mereka dalam bekerja diselimuti rasa aman dan tidak khawatir bila terjadi kecelakaan sehingga dapat bekerja secara maksimal.

\footnotetext{
${ }^{11}$ Lihat, Undang-undang tentang keselamatan kerja Nomor 1 tahun 1970 pasal 2,

${ }^{12}$ Lihat,Undang-Undangan Permenakertrans RI Nomor 1 Tahun 1978 tentang Keselamatan dan Kesehatan Kerja dalam Pengangkutan dan Penebangan Kayu secara nyata
} 


\section{Tanggung Jawab Korporasi Yang Ideal Bagi Korban Kecelakaan Kerja Berbasis Keadilan}

Ada dua macam perlindungan hukum, yaitu perlindungan hukum preventif dan perlindungan hukum represif. ${ }^{13}$

1. Perlindungan hukum preventif

Perlindungan hukum preventif artinya rakyat diberikan kesempatan untuk mengajukan keberatan atau pendapatnya sebelum keputusan pemerintah mendapat bentuk yang defmitive. ${ }^{14}$

2. Perlindungan hukum represif

Perlindungan hukum represif, yaitu perlindungan hukum yang diberikan setelah adanya sengketa. Perlindungan hukum represif ini bertujuan untuk menyelesaikan sengketa. ${ }^{15}$

Dalam hukum ketenagakerjaan bentuk perlindungan hukum yang diberikan berupa perlindungan hukum dibidang keamanan kerja dimana baik dalam waktu yang relatif singkat atau lama akan aman dan ada jaminan keselamatan bagi pekerja. Dengan adanya perlindungan hukum terhadap pekerja, negara mewajibkan kepada pengusaha untuk menyediakan alat keamanan kerja bagi pekerja. Dalam hal pertanggung jawaban terhadap pekerja apabila terjadi kecelakaan kerja ketika melaksanakan kewajibannya dalam pekerjaan, maka pengusaha akan menanggung beban yang timbul secara materiil dengan memberikan penggantian dari biaya yang timbul akibat kecelakaan kerja. ${ }^{16}$

Perlindungan hukum diartikan sebagai suatu bentuk tindakan atau perbuatan hukum pemerintah yang diberikan kepada subjek hukum sesuai dengan hak dan kewajibannya yang dilaksanakan berdasarkan hukum positif di Indonesia. Perlindungan hukum timbul karena adanya suatu hubungan hukum. Hubungan hukum adalah interaksi antara subjek hukum yang memiliki relevansi hukum atau mempunyai akibat hukum (timbulnya hak dan kewajiban). ${ }^{17}$

Dalam pembangunan nasional peran tenaga kerja sangat penting, sehingga perlindungan terhadap tenaga kerja sangat diperlukan untuk menjamin hak-hak dasar pekerja/buruh dan menjamin kesamaan kesempatan serta perlakuan tanpa diskriminasi atas dasar apapun untuk mewujudkan kesejahteraan pekerja/buruh. ${ }^{18}$ Hak tenaga kerja adalah sebagai berikut:

1. Imbalan kerja (gaji, upah dan sebagainya) sebagaimana telah diperjanjikan bila ia telah melaksanakan kewajiban.

2. Fasilitas dan berbagai tunjangan/dana bantuan yang menurut perjajian akan diberikan oleh pihak majikan/perusahaan kepadanya.

3. Perlakuan yang baik atas dirinya melalui penghargaan dan penghormatan yang layak, selaras dengan harkat dan martabatnya sebagai manusia.

4. Perlakuan yang adil dan seimbang antara dirinya dan kawan-kawannya, dalam tudas dan penghasilannya masing-masing dalam angka perbandingan yang sehat.

5. Jaminan kehidupan yang wajar dan layak dari pihak majikan/perusahaan.

6. Jaminan perlindungan dan keselamatan diri dan kepentingan selama hubungan kerja berlangsung.

7. Penjelasan dan kejelasan status, waktu dan cara kerjanya pada majikan/perusahaan. ${ }^{19}$

8. Menyatakan keberatan melakukan pekerjaan bila syarat keselamatan dan kesehatan kerja serta alat

\footnotetext{
${ }^{13}$ Philipus M. Hadjon, 1987, Perlindungan Hukum Bagi Rakyat Indonesia, Bina Ilmu Surabaya, hal.1

${ }^{14}$ Hadjon , dkk, 2002, Pengantar Administrasi Negara, Gajah Mada University, Yogyakarta,hal. 3.

${ }^{15}$ Zaeni Asyhadie, 2008, Hukum Kerja (Hukum Ketenagakerjaan Bidang Hubungan Kerja), edisi revisi 2, PT.RajaGrafindo Persada, Jakarta, hal. 20. (selanjutnya disebut Zani Ashyhadie II)

${ }^{16}$ Soedarjadi, 2008, Hukum Ketenagakerjaan di Indonesia, Pustaka Yustisia, Yogyakarta,hal,53

${ }^{17}$ Soeroso, 2006, Pengahantar Ilmu Hukum, Cetakan Kedelapan, Penerbit Sinar Grafika, Jakarta, hal. 49

${ }^{18}$ Adrian Sutedi, 2011, Hukum Perburuhan, Ed-1. Cet.2,Sinar Grafika, Jakarta, hal. 14.

${ }^{19}$ A. Ridwan Halim, 1990, Hukum Perburuhan Dalam Tanyak Jawab, Balai Akasara, Jakarta, hal. 45
} 
perlindungan diri yang diwajibkan tidak dipenuhi, kecuali dalam toleransi khusus yang ditetapkan lain oleh pegawai pengawas.

Dengan Undang-Undang ini dibentuk BPJS Ketenagakerjaan yang menyelenggarakan program jaminan kecelakaan kerja, jaminan hari tua, jaminan pensiun, dan jaminan kematian. Pasal 15 Ayat (1) UU BPJS, menyebutkan "Pemberi kerja secara bertahap wajib mendaftarkan dirinya dan pekerjanya sebagai peserta kepada badan penyelenggara jaminan sosial sesuai dengan program jaminan sosial yang diikuti". ${ }^{20}$

\section{PENUTUP}

\section{Kesimpulan}

1. Sistem manajemen kerja yang telah di evaluasi oleh pemerintah maupun pihak dari perusahaan bahwa kualitas sumber daya manusia perlu ditingkatkan agar terwujud tenaga kerja yang berkualitas, berkomptensi, dan efektivitas serta efisien agar tercapai tujuan perusahan tersebut.

2. Untuk mengatasi permasalahan ini perlu ada tindakan khusus dari pemerintah atau lembaga K3 yang ada di Indonesia untuk mengatasi masalah ini misalnya dengan memberikan penyuluhan terhadap warga desa tentang betapa pentingnya tentang keselamatan dan kesehatan kerja di lingkungan kerja agar mereka menyadari betapa pentingnya penerapan K3 di lingkungan kerja. Dengan salah satu cara ini pemerintah sudah melaksanakan kebijakan perundang-undangan Permenakertrans RI No 1 Tahun 1978 tentang Keselamatan dan Kesehatan Kerja dalam Pengangkutan dan Penebangan Kayu secara nyata. ${ }^{21}$

3. Perlindungan hukum preventif artinya rakyat diberikan kesempatan untuk mengajukan keberatan atau pendapatnya sebelum keputusan pemerintah mendapat bentuk yang defmitive. Perlindungan hukum represif perlindungan hukum yang diberikan setelah adanya sengketa. Perlindungan hukum represif ini bertujuan untuk menyelesaikan sengketa.

\section{Saran}

a. Untuk menanggulangi resiko seperti kecelakaan kerja, pihak PT semen gresik seharusnya lebih mengoptimalkan upaya kesehatan dan keselamatan kerja terhadap pekerjanya.

b. Sebaliknya pihak PT semen gresik memberikan sosialisasi terhadap pekerja bahwa betapa pentingnya keselamatan kerja serta mengenai adanya program jaminan sosial pemerintah yaitu BPJS.

c. Sistem pengawasan dan penegak hukum bagi para pelanggar sistem keselamatan dan kesehatan kerja lebih ditingkatkan lagi supaya dapat menimbulkan efek jera, baik karyawan maupun perusahaan yang melakukan pelanggaran tersebut.

\section{DAFTAR PUSTAKA}

\section{A. Ridwan Halim, 1990, Hukum Perburuhan Dalam Tanyak Jawab, Balai Akasara, Jakarta}

Adrian Sutedi, 2011, Hukum Perburuhan, Ed-1. Cet.2,Sinar Grafika, Jakarta

Asri Wijayanti, 2009, Hukum Ketenagakerjaan Pasca Reformasi, Sinar Grafika, Jakarta

Bandingkan dengan Undang-Undang Nomor 1 Tahun 1970 tentang Keselamatan Kerja

\footnotetext{
${ }^{20}$ Wiwiho Soedjono, 2000, Hukum Perjanjian Kerja, Bina Aksara, Jakarta, hal. 42.

${ }^{21}$ Lihat,Undang-Undangan Permenakertrans RI Nomor 1 Tahun 1978 tentang Keselamatan dan Kesehatan Kerja dalam Pengangkutan dan Penebangan Kayu secara nyata
} 
Darwin Prinst, Hukum Ketenagakerjaan Indonesia (Buku Pegangan Pekerja Untuk Mempertahankan hak-haknya), Penerbit Citra Aditya Bakti, Bandung, 1994

Dian Octaviani Saraswati, "Perlindungan Hukum Keselamatan dan Kesehatan Terhadap tenaga Kerja di Perusahaan tenun PT. Musitex Kabupaten Pekalongan" Tesis Mahasiswa Universitas Diponegoro (2017

Hadjon , dkk, 2002, Pengantar Administrasi Negara, Gajah Mada University, Yogyakarta,

http://poskotanews.com/2012/01/12/pelanggar-k3-bisa-dipidana/ diakses pada tanggal 7 Desember 2017 pada Pukul 17.10

Maimun, 2004, Hukum Ketenaga Kerjaan Suatu Pengantar, , Pradnya Paramita, Jakarta

Philipus M.Hadjon, 1987, Perlindungan Hukum Bagi Rakyat Indonesia, Bina IImu Surabaya

R. Joni Bambang S., S.H., MM, 2013, Hukum Ketenagakerjaan, Bandung: Pustaka Setia

Soedarjadi, 2008, Hukum Ketenagakerjaan di Indonesia, Pustaka Yustisia, Yogyakarta

Soerjono Soekanto, 2013, Faktor-Faktor Yang Mempengaruhi Penegakan Hukum, Cet. ke-12, Jakarta, Rajawali Press.

Soeroso, 2006, Pengahantar Ilmu Hukum, Cetakan Kedelapan, Penerbit Sinar Grafika, Jakarta, hal. 49

Wiwiho Soedjono, 2000, Hukum Perjanjian Kerja, Bina Aksara, Jakarta.

Zaeni Asyhadie, 2008, Hukum Kerja (Hukum Ketenagakerjaan Bidang Hubungan Kerja), edisi revisi 2, PT.RajaGrafindo Persada, Jakarta 